\title{
Development of prefabricated insulation elements for buildings with aerated autoclaved concrete walls
}

\author{
Peep Pihelo ${ }^{1 *}$, and Targo Kalamees ${ }^{2,1}$ \\ ${ }^{1}$ nZEB Research Group, Tallinn University of Technology, Tallinn, Estonia \\ ${ }^{2}$ Smart City Center of Excellence (Finest Twins), Tallinn University of Technology, Tallinn, Estonia
}

\begin{abstract}
An extensive need for the refurbishment and renewal of existing building stock has been the focus of consideration for many decades, principally because of the high global energy consumption and pollution levels. This paper presents the results of the analysis of certain sets of timber frame prefabricated insulation elements for the major renovation of an apartment building. The hygrothermal measurements were taken, and a series of combinations with elements were analysed using building performance simulation software to compare the main hygrothermal properties. The critical initial moisture content for the surface section of the aerated autoclaved concrete (AAC) panel is $w=65 \mathrm{~kg} / \mathrm{m}^{3}$ at a depth of $15 \mathrm{~mm}$ and $w=39 \mathrm{~kg} / \mathrm{m}^{3}$ at a depth of $70 \mathrm{~mm}$. The results showed that before the design and installation of insulation elements, thorough hygrothermal analysis of the original external envelope, with actual climatic conditions and moisture loads, must be realized.
\end{abstract}

\section{Introduction}

Majority of residential buildings, built after World War II (WWII) are in age and conditions where the technical improvement is needed [1-5]. Therefore, the considered measures must be taken. The building envelope of a renovated building should be more highly insulated than some years ago [6-8]. Market participants must find ways to improve the quality of design [9] and installation to follow-up increasing requirements of energy performance and hygrothermal performance of the buildings [10].

External thermal insulation composite systems (ETICS) have been used for decades for the renovation of masonry, concrete and other substrates [11]. ETICS primarily fulfil the functions of thermal insulation and protecting the building against the influences of weather but many authors [12-14] have pointed out that durability issues, including degradation of the surface and the ageing of the materials are the most common problems in ETICS to deal with. Installing timber (or other similar) framing manually to the external envelope, filled between with insulation layers and covered by wind and weather protective facade layers, is another common method for the refurbishment as well as for building extensions.

Both methods described are based on fieldwork, consisting of long-lasting manual work and scaffolding use. In the unescapable weather conditions and varying quality of the installation, the results obtained are not always in agreement with expectations. Therefore, the market participants are in search of alternatives to improve and rethink the existing building stock and its quality by means of prefabrication and with fewer disturbance to the proprietors of the buildings.

One of the innovative ways of major renovation is the application of prefabricated elements, which has the potential to reduce cost and renovation time, to minimise disturbance for inhabitants and enhance quality and performance in terms of energy efficiency [15-17].

In the current research, the most relevant properties and hygrothermal performance of prefabricated insulation elements were analysed, usable in the deep renovation of existing apartment buildings, whose walls are constructed of aerated autoclaved concrete (AAC).

\section{Methods}

\subsection{Case study building}

AAC large panel buildings are the third most dominant structural system in Estonia after concrete and brick apartment buildings (see Fig. 1), but it is less analysed and supported by typical renovation solutions. This building type was widely built in the 1970s-90s in suburban and rural areas. A 3-story apartment building with a total area of $2415 \mathrm{~m}^{2}$, constructed in 1986 (see Fig. 2) is to be renovated, using prefabricated timber frame insulation elements [18] and the circular renovation concept [19].

The building has natural passive stack ventilation (separate ventilation shaft for every apartment) with supply air intake from air leakages, mostly through the windows.

\footnotetext{
*Corresponding author: peep.pihelo@taltech.ee
} 


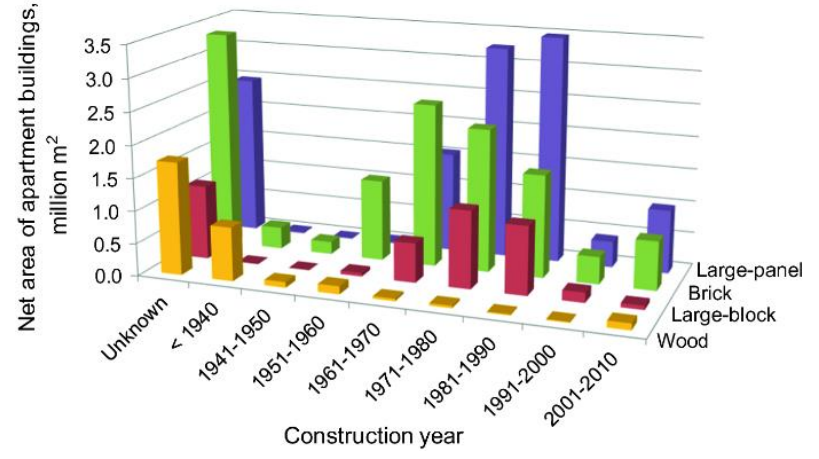

Fig. 1. Apartment buildings by the net area and by the construction types in Estonia [20].
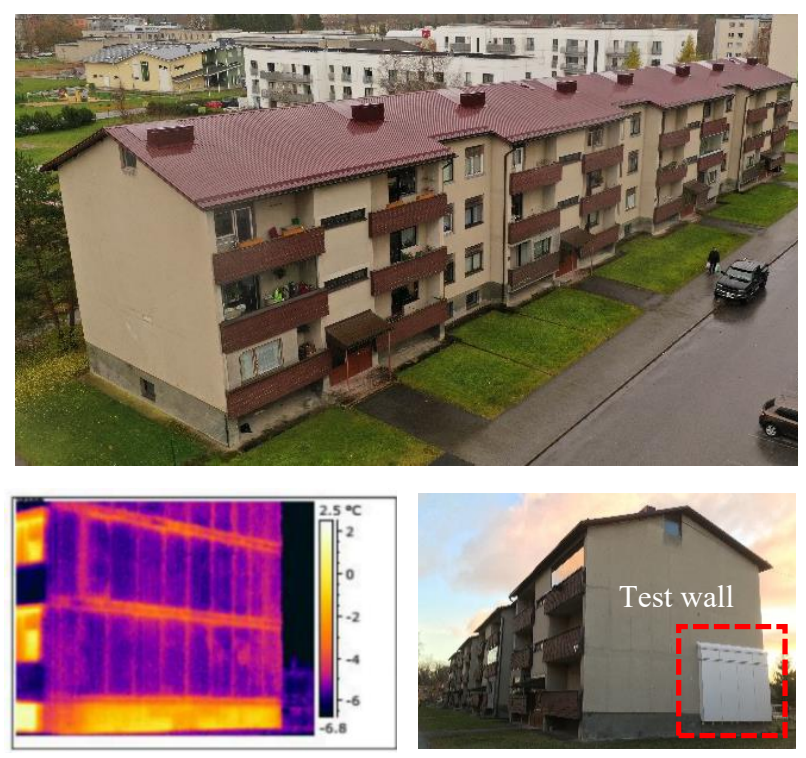

Fig. 2. Overview (top) and thermal bridges on the external wall (bottom left) of the case study building before renovation. Installed test element on the SW wall (bottom right).

The building has district heating as a heat source for room heating (the distribution system is a one-pipe hydronic radiator system) and the heating of domestic hot water.

\subsection{Simulations}

To analyse the hygrothermal performance of the external walls, simulations with the software Delphin [21,22] were conducted. Delphin is a simulation program for coupled heat, moisture and matter transport in porous building materials and it is used for different applications, e.g. the calculation of mould growth risks taking into consideration climate impacts, structure conditions and materials modelling. Table 1 shows the properties of the materials used in simulations. The simulation model is calibrated based on the field measurements [23] and in the current study, AAC was used as the existing external wall.

For climate conditions, Estonian moisture reference year [24] and critical indoor hygrothermal loads (indoor moisture excess $\Delta v=6 \mathrm{~g} / \mathrm{m}^{3}$ during winter) were applied [25].
Table 1. Properties of materials in structures studied.

\begin{tabular}{|c|c|c|c|c|}
\hline Material & $\begin{array}{l}\text { Thermal } \\
\text { conduc- } \\
\text { tivity } \lambda \text {, } \\
W /(\mathbf{m} \cdot \mathbf{K})\end{array}$ & $\begin{array}{l}\text { Water } \\
\text { vapour } \\
\text { resistance } \\
\text { factor } \mu,-\end{array}$ & $\begin{array}{c}\text { Density } \\
\rho, \\
\mathrm{kg} / \mathbf{m}^{3}\end{array}$ & $\begin{array}{c}\text { Water } \\
\text { absorption } \\
\text { coefficient } \\
\mathbf{A}_{\mathrm{w}}, \mathrm{kg} /\left(\mathbf{m}^{2} \cdot \mathbf{s}^{0.5}\right)\end{array}$ \\
\hline $\begin{array}{l}\text { Autoclaved } \\
\text { aerated concrete }\end{array}$ & 0.200 & 8.00 & 810 & 0.0441 \\
\hline Timber (pine) & 0.130 & 40.0 & 450 & 0.0155 \\
\hline $\begin{array}{l}\text { MW insulation } \\
\text { MW board with }\end{array}$ & 0.035 & 1.20 & 22 & \\
\hline $\begin{array}{l}\text { facing } \\
\text { Fibre cement }\end{array}$ & 0.031 & 1.80 & 105 & \\
\hline board & 0.263 & 17.5 & 1350 & 0.0569 \\
\hline Gypsum board & 0.190 & 7.90 & 774 & 0.0760 \\
\hline $\begin{array}{l}\text { Oriented strand } \\
\text { board (OSB) } \\
\text { Air and vapour } \\
\text { barrier }\end{array}$ & 0.102 & 190 & 640 & 0.0018 \\
\hline $\begin{array}{l}\left(0.2 \mathrm{~m} \leq S_{\mathrm{d}} \leq 5 \mathrm{~m}\right)^{*} \\
\text { PE-foil }\end{array}$ & * 0.230 & 1000 & 460 & 0.0001 \\
\hline$\left(S_{\mathrm{d}} \geq 50 \mathrm{~m}\right)^{*}$ & 0.400 & 89000 & 980 & \\
\hline
\end{tabular}

\subsection{Performance assessment}

To assess the hygrothermal performance of the building envelope, the risk of mould growth as a performance criterion was used. The Finnish mould growth model $[26,27]$ takes into account fluctuating temperature and humidity conditions, growth surface and results in the mould index $(M)$.

According to the mould index model, the mould growth sensitivity class 'sensitive' was used for the planed timber, timber-based materials and for gypsum board with paper. Untreated wood (sapwood), in class 'very sensitive', was not used in analysed structures. For other materials, the class 'medium resistant' was set. The safe value of the mould index was set in the current study to level $M<1$ (no mould growth) and critical value to level $M=2$ (several local mould growth colonies on the surface). Therefore, the mould index $1 \leq M<2$ is considered as a low risk of mould growth (small amounts of mould on the surface, the initial stage of growth) [28].

\subsection{Construction type and materials}

The external walls, to be insulated in the process of a deep renovation of an apartment building, are made of AAC panels with a thickness of $300 \mathrm{~mm}$ (see Fig. 3, layer 7). AAC panels are covered from external side with thin (1$5 \mathrm{~mm}$ ) lime-cement plaster, which is porous and locally cracked. The structure of the prefabricated additional thermal insulation element is based on timber frames $(\mathrm{c} / \mathrm{c}$ $600 \mathrm{~mm}$ ) with $195 \mathrm{~mm}$ of mineral wool (MW) insulation (layer 4), where air and vapour tightness from the inner side is guaranteed with an air and vapour barrier membrane (layer 5) and covered with a wind barrier layer (layer 3) from the external side.

The performance of the most common on the market wind barrier boards was compared (MW board with special facing, fibre cement board, gypsum board without paper, OSB). The fibre cement board was selected as the 
first choice for a wind barrier because of its rigidity and high fire resistance class $\left(A_{2}, s_{1}-d_{0}\right)$, which is required for apartment buildings facades. Ventilated air gap (layer 2) with vertical timber battens $28 \times 70 \mathrm{~mm}$ contributes to the drying-out of built-in moisture and facade boarding ensures the weatherproof protection of envelope structures (layer 1). To minimize convection in between the structures and to fill the gap between the uneven original wall surface and the prefabricated timber frame insulation element, a mineral wool buffering layer is foreseen on prefabricated elements back side (layer 6). A buffering layer can be fixed in a zigzag pattern with strings which are released after the element is installed or by using adhesives.

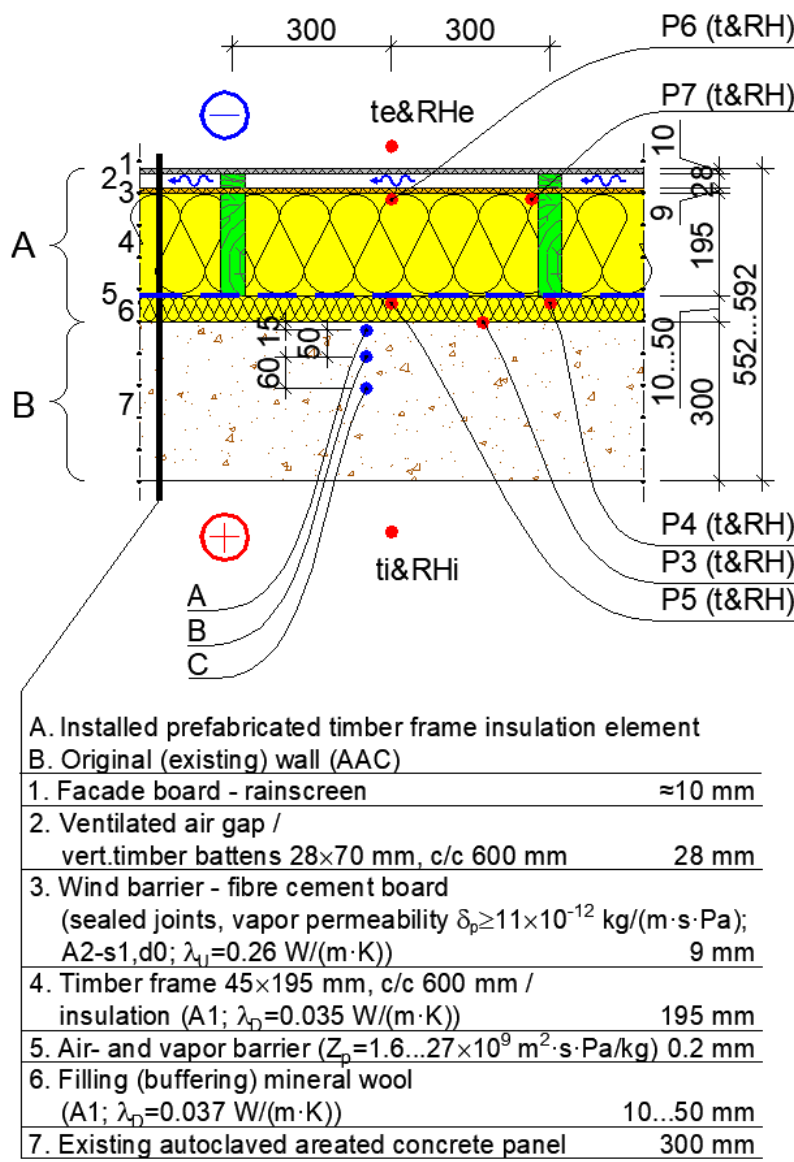

Fig. 3. Horizontal section 1-1 of the test wall.

The buffering layer and all other layers of elements are installed in a factory and covered with plastic foil to protect against weather conditions during transport and on the building site. The prefabricated elements are covered with facade boarding at the factory, except for some minor points that required for installation and/or lifting at the building site. The designed thermal transmittance of the AAC panel external wall, insulated additionally with prefabricated timber frame insulation elements, is $U_{\text {external wall }}=0.14 \mathrm{~W} /\left(\mathrm{m}^{2} \cdot \mathrm{K}\right)$.

Compared to the previously developed wall system [18], three changes were done to have the production of insulation elements simpler and cheaper:

- To decrease production steps in the factory, the crossdirectional laths have been renounced. This was possible because of the lower energy performance target. Now, the beams are crossing the insulation and the thermal efficiency of the wall is lower. Without cross lathing, more insulation is needed to get the same thermal transmittance;

- A mineral wool wind barrier with special facing, with a high thermal resistance and vapour permeability was changed to rigid fibre cement board / gypsum board. This change makes hygrothermal performance of the wall more complicated because the wind barrier layer has lower vapour permeability and thermal resistance;

- The performance of test elements was measured at critical points (see Fig. 2, Fig. 3, Fig. 4) with and without a special air and vapour barrier. Wall without an air and vapour barrier membrane has lower cost and allows higher moisture flux to dry out the constructional moisture from original wall, but with that, it has a higher mould growth risk behind the wind barrier. However, without the membrane, it is difficult to guarantee the airtightness of the building envelope.

\subsection{Measurements}

In Fig. 3 are shown locations of the analysed points (P3 to P7) of the case study building where temperature $(t)$ and relative humidity $(R H)$ were analysed. Two test elements with sizes $2.4 \times 3 \mathrm{~m}$ (with and without an air and vapour barrier) were installed to the end-wall, see Fig. 3, Fig. 4 for testing and measuring the performance of the insulated envelope.

To determine the initial moisture content of the original AAC panel, samples from different parts and depths of the AAC panel were drilled out and taken to the lab for testing. Samples were weighed promptly, measured and then dried (dehydrated) in the oven at the lab according to standard EN 1353 [29]. Using the mass difference, the moisture content $w\left(\mathrm{~kg} / \mathrm{m}^{3}\right)$ and $u(\mathrm{~kg} / \mathrm{kg})$ of the material specimens was consequently defined.

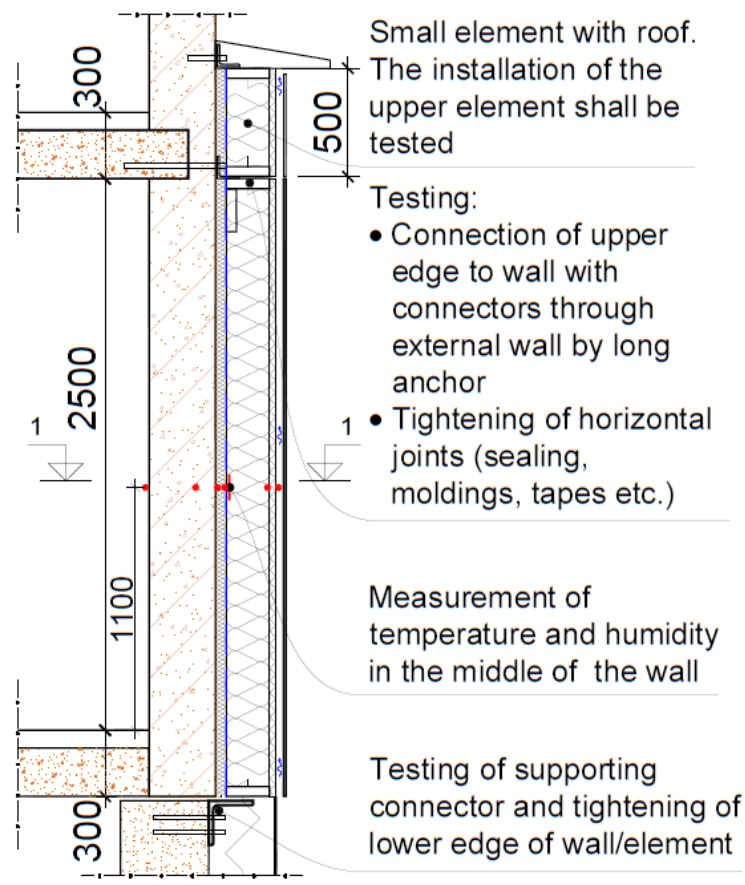

Fig. 4. Vertical section of the test wall. 


\section{Results}

\subsection{Initial moisture content and distribution of moisture in the existing wall}

\subsubsection{Before the renovation}

The measured and calculated moisture content of the existing AAC wall is shown in Fig. 5. Measured samples were drilled out from wall in the autumn, with slight rain. The results show that the external part of the AAC panel (from the outdoor surface $<50 \mathrm{~mm}$ ) has a markedly higher moisture content than the internal part. We can see a decrease in the moisture content, starting from the middle $(150 \mathrm{~mm})$ of the wall to inwards. The side wall of the loggia is open to weather impacts from both sides, but the inner side of the loggia wall has no considerable impact from precipitation.

To determine possible critical moisture content and the influence of rain on an AAC panel without additional external insulation (before renovation), simulations using a calibrated model of Delphin were conducted. Good agreement in the results of measured (solid lines) and calculated data (dotted lines) was reached. See Fig. 5.

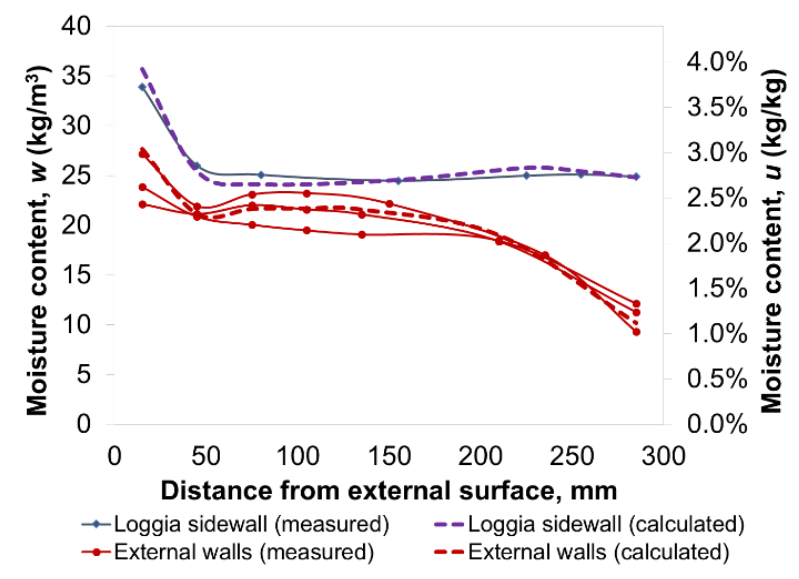

Fig. 5. Measured (solid lines) and calculated (dotted lines) moisture content of AAC. Samples were taken from different locations and depths of the external walls in Oct 2019.

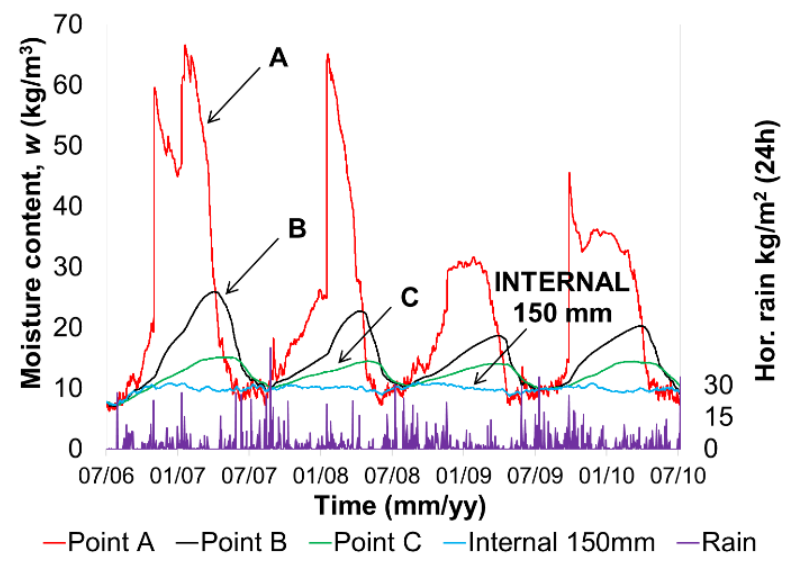

Fig. 6. Moisture redistribution in the AAC external wall without external additional insulation (faced to south-west). See Fig. 3 for the locations of the points.
Moisture distribution at different depths of the wall and precipitation during a randomly selected 4-year period is shown in Fig. 6. The impact of the rain and the redistribution of the moisture are very clearly visible. The moisture content is lower during summer and the highest during autumn-winter period. The dry-out time after heavy rainfall in the external sections of the AAC panel could be remarkably long.

Moisture distribution in the wall was analysed with local climate data of 43 years (1970-2012). See the values of the 90-percentile of moisture content in Fig. 7 (i.e. $10 \%$ of results have higher moisture content). The results of the moisture content in the AAC panel at different depths and seasons show a noticeably large variation, both in the depth of the AAC panel as well as in the different months.

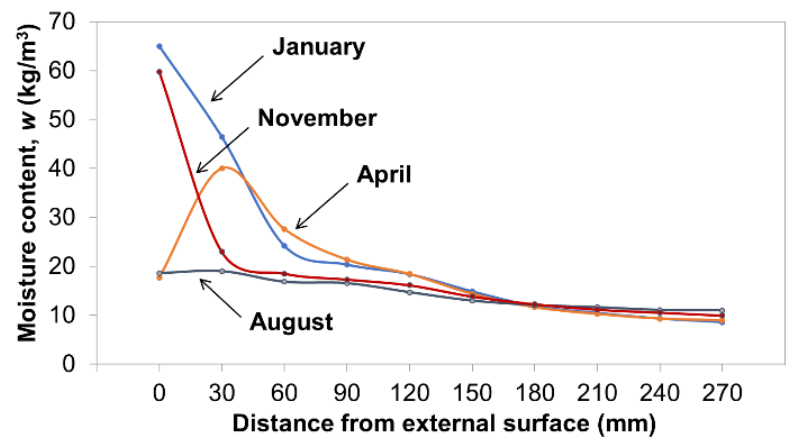

Fig. 7. Distribution of moisture content in AAC panel.

To proceed with the deterministic hygrothermal design of insulation elements, the values of the 90percentile of moisture content in points $\mathrm{A}, \mathrm{B}$ and $\mathrm{C}$ (see locations in Fig. 3) were calculated, with the help of moisture content calculation data, obtained at different depths and months. The determined initial moisture content levels in AAC panel with local climate and winddriven rain loads are presented in Fig. 8.

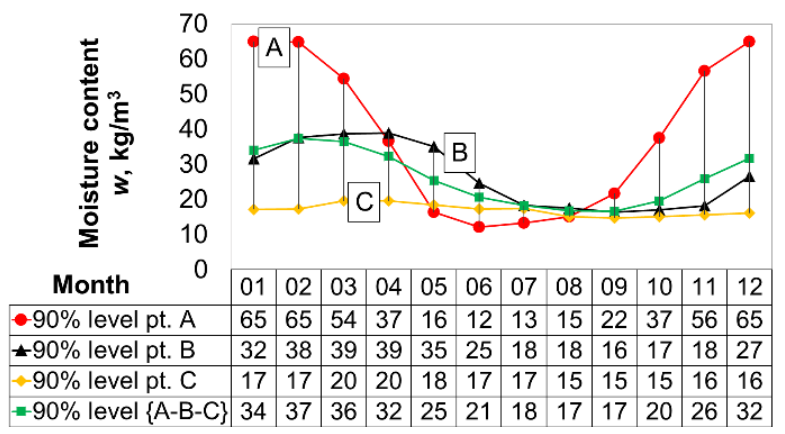

Fig. 8. Monthly moisture content in the AAC panel at different depths during the studied period (1970-2012) without external additional insulation. See Fig. 3 for the locations of the points.

Results obtained describe the importance of the evaluation of the hygrothermal condition of the external walls in the design process, before renovation and during the installation of additional insulation layers. Even slight wind-driven rainfall may cause the wall to assimilate the amount of water, which is many times higher than the equilibrium state. These circumstances are very important to consider in the design process when choosing layers for 
the insulation panels and to study and find the appropriate season and weather for the installation works to take place.

The water, accumulated in colder seasons in the outer parts, is moving deeper into the pores of the AAC panel and already in the second quarter of the year, the moisture level is higher at points $B$ and $C$ than on the surface at point A. Because of the moisture redistribution, it is essential to drill out the samples from different depths and measure the moisture content (e.g. in points A, B, C). The critical initial moisture content (design value) for the surface section of the AAC panel is $65 \mathrm{~kg} / \mathrm{m}^{3}$ at a depth of $15 \mathrm{~mm}$ and $39 \mathrm{~kg} / \mathrm{m}^{3}$ at a depth of $70 \mathrm{~mm}$.

\subsubsection{After the renovation}

Consequently, the capability of moisture dry-out from the AAC panel after the installation of the prefabricated insulation elements was calculated at points $\mathrm{A}, \mathrm{B}$ and $\mathrm{C}$ with corresponding moisture loads (e.g. wind-driven rain) which have an impact on installed prefabricated elements.

The moisture redistribution, exposed in Fig. 9, describes the differences in water content in the external layer at different depths and the corresponding dry-out time. The dry-out time to reach the equilibrium state of AAC panel after installation of insulation elements is up to 6-8 months, when air and vapour barrier with varying water vapour resistance $\left(0.2 \mathrm{~m}<S_{\mathrm{d}}<5 \mathrm{~m}\right)$ was used. Results confirm that the amount of drying out moisture is high $\left(<55 \mathrm{~kg} / \mathrm{m}^{3}\right)$ and it should be considered in hygrothermal design and in renovation process.

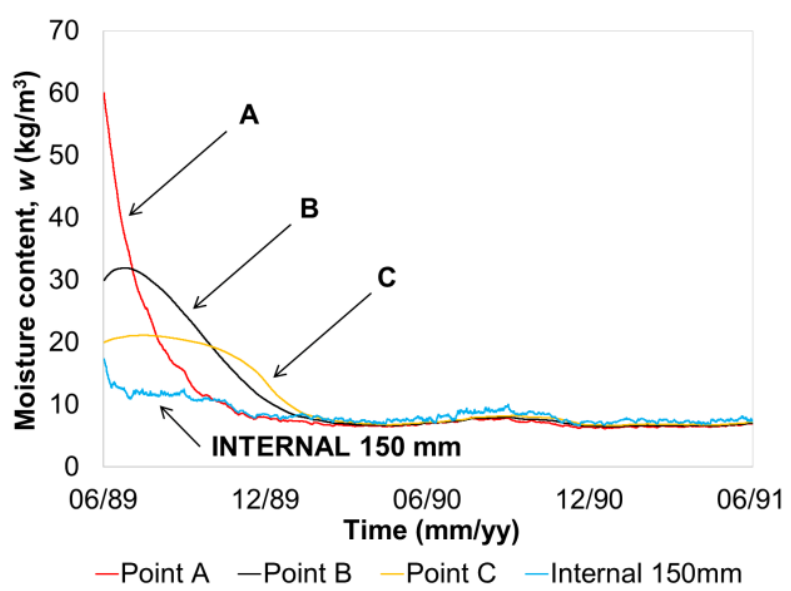

Fig. 9. Moisture dry-out and redistribution in the AAC panel after the installation of the prefabricated insulation elements with air and vapour barrier with varying vapour resistance.

\subsection{Evaluation of the hygrothermal performance of the prefabricated insulation element}

To simulate the critical conditions at various seasons at the start of the installation of the prefabricated timber frame insulation elements, the temperature, relative humidity (see Fig. 10) and mould index $M$ (see Fig. 11) were calculated for studied constructions. 3 different scenarios of initial moisture content of the AAC were used in calculations:
- The installation in the autumn-winter period ' $65-30$ 20 , i.e. $w=65 \mathrm{~kg} / \mathrm{m}^{3}$ in pt.A, $w=30 \mathrm{~kg} / \mathrm{m}^{3}$ in pt.B, $w=20 \mathrm{~kg} / \mathrm{m}^{3}$ in pt.C;

- The installation in the spring period ' $55-35-20$ ', $w=55 \mathrm{~kg} / \mathrm{m}^{3}$ in pt.A, $w=35 \mathrm{~kg} / \mathrm{m}^{3}$ in pt.B, $w=20 \mathrm{~kg} / \mathrm{m}^{3}$ in pt.C;

- The installation in the summer period '20-25-15', $w=20 \mathrm{~kg} / \mathrm{m}^{3}$ in pt.A, $w=25 \mathrm{~kg} / \mathrm{m}^{3}$ in pt.B, $w=15 \mathrm{~kg} / \mathrm{m}^{3}$ in pt.C.

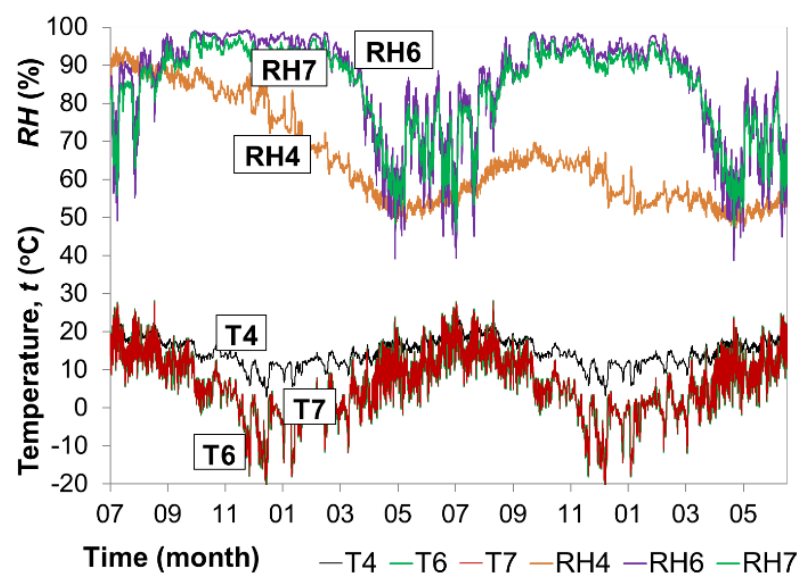

Fig. 10. Temperature $(t)$ and relative humidity $(R H)$ at critical points with scenario ' $65-30-20$ ' and with fibre cement wind barrier board. See Fig. 3 for the locations of the points.

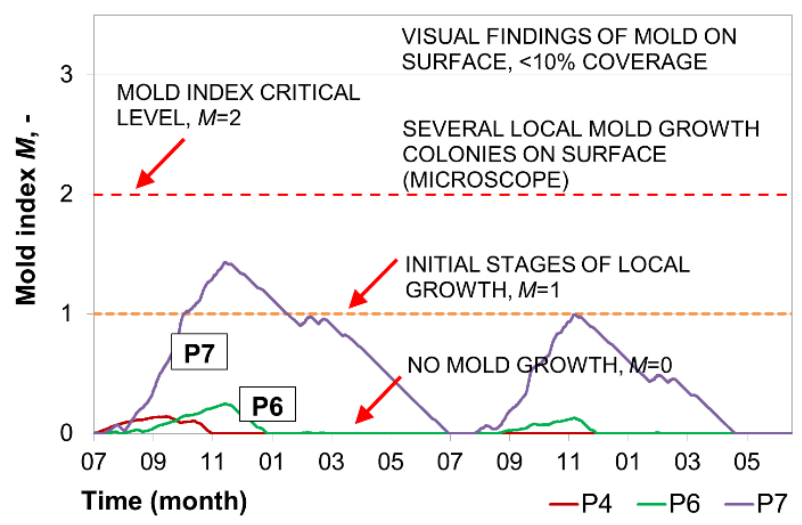

Fig. 11. The calculated mould index $M$ at critical points with scenario ' $65-30-20$ ' and with a fibre cement wind barrier board. See Fig. 3 for the locations of the points.

The mould growth risk of an externally insulated AAC wall with different wind barriers and installation seasons (i.e. with different initial moisture content) is shown in Table 2.

The results confirm that from the point of hygrothermal performance, the best solution is a MW wind barrier because of its high thermal resistance and vapour permeability. The fibre cement board wind barrier could be an option as well, but its vapour permeability should be controlled each time because there could be other quite vapour tight fibre cement products on the market. The use of gypsum board (without paper surface) could also be considered by analysing the weather forecast (rain), installation season and moisture content of the original wall. 
Table 2. The risk of mould growth (mould index $M$ ) of an externally insulated AAC wall with different wind barriers and installation seasons (i.e. with different initial moisture content). In the coloured cells are shown sensitivity classes of analysed points.

\begin{tabular}{|c|c|c|c|c|c|c|c|c|c|}
\hline \multirow{3}{*}{$\begin{array}{c}\begin{array}{c}\text { Analysed } \\
\text { point }\end{array} \\
\begin{array}{c}S_{\mathrm{d}} \text { of vapour } \\
\text { barrier }(\mathrm{m})\end{array}\end{array}$} & \multicolumn{9}{|c|}{ Installation season of prefabricated insulation elements } \\
\hline & \multicolumn{3}{|c|}{ Autumn-Winter } & \multicolumn{3}{|c|}{ Spring } & \multicolumn{3}{|c|}{ Summer } \\
\hline & $\mathbf{0}$ & $0.2-5$ & $\geq \mathbf{5 0}$ & $\mathbf{0}$ & $0.2-5$ & $\geq \mathbf{5 0}$ & $\mathbf{0}$ & $0.2-5$ & $\geq \mathbf{5 0}$ \\
\hline \multicolumn{10}{|c|}{ Wind barrier - mineral wool board w/special facing $30 \mathrm{~mm}$} \\
\hline $\mathbf{P 3}$ & MR & MR & MR & MR & MR & MR & MR & MR & MR \\
\hline P4 & $\mathrm{S}$ & MR & MR & $\mathrm{S}$ & MR & MR & $\mathrm{S}$ & MR & MR \\
\hline P5 & MR & MR & MR & MR & MR & MR & MR & MR & MR \\
\hline P6 & MR & MR & MR & MR & MR & MR & MR & MR & MR \\
\hline P7 & $\mathrm{S}$ & $\mathrm{S}$ & $\mathrm{S}$ & $\mathrm{S}$ & $\mathrm{S}$ & $\mathrm{S}$ & $\mathrm{S}$ & $\mathrm{S}$ & $\mathrm{S}$ \\
\hline \multicolumn{10}{|c|}{ Wind barrier - fibre cement board $9 \mathrm{~mm}$} \\
\hline P3 & MR & MR & MR & MR & MR & MR & MR & MR & MR \\
\hline $\mathbf{P 4}$ & $\mathrm{S}$ & MR & MR & $\mathrm{S}$ & MR & MR & $\mathrm{S}$ & MR & MR \\
\hline P5 & MR & MR & MR & MR & MR & MR & MR & MR & $\overline{M R}$ \\
\hline P6 & MR & MR & MR & MR & MR & MR & MR & MR & MR \\
\hline P7 & $\mathrm{S}$ & S & S & S & S & S & S & S & S \\
\hline \multicolumn{10}{|c|}{ Wind barrier - gypsum board without paper surface $9 \mathrm{~mm}$} \\
\hline P3 & MR & MR & MR & MR & MR & MR & MR & MR & MR \\
\hline P4 & $S$ & MR & MR & $S$ & MR & MR & $S$ & MR & MR \\
\hline P5 & MR & $\overline{M R}$ & MR & MR & $\overline{M R}$ & MR & MR & $\overline{M R}$ & MR \\
\hline P6 & MR & MR & MR & MR & MR & MR & MR & MR & MR \\
\hline P7 & $\mathrm{S}$ & $\mathrm{S}$ & $\mathrm{S}$ & $\mathrm{S}$ & $\mathrm{S}$ & $\mathrm{S}$ & $\mathrm{S}$ & $\mathrm{S}$ & $\mathrm{S}$ \\
\hline \multicolumn{10}{|c|}{ Wind barrier - oriented strand board (OSB) $12 \mathrm{~mm}$} \\
\hline P3 & MR & MR & MR & MR & MR & MR & MR & MR & MR \\
\hline P4 & $\mathrm{S}$ & MR & MR & $\mathrm{S}$ & MR & MR & $\mathrm{S}$ & MR & MR \\
\hline P5 & MR & MR & MR & MR & $\overline{M R}$ & MR & MR & $\overline{M R}$ & MR \\
\hline P6 & S & S & $\mathrm{S}$ & $\mathrm{S}$ & S & S & $\mathrm{S}$ & $\mathrm{S}$ & $\mathrm{S}$ \\
\hline P7 & $\mathrm{S}$ & S & $\mathrm{S}$ & S & $\mathrm{S}$ & $\mathrm{S}$ & S & S & $S$ \\
\hline
\end{tabular}

Risk of mould formation is categorized by colours:

- Green - no mould growth risk, $M<1$;

- Yellow - minor mould growth risk, $1 \leq M<2$;

- Red - high mould growth risk, $M \geq 2$.

Mould growth sensitivity classes for each point are marked according to the mould growth model:

- MR ('medium resistant'): mineral wool, fibre cement board, gypsum board without paper;

- S ('sensitive'): planed (processed) wood, OSB, gypsum board with paper.

The use of gypsum board with paper or timber-based boards (e.g. OSB, plywood) is not suggested as an option as their thermal resistance is low, mould growth sensitivity is high and vapour resistance of dense board is too high to let the drying-out moisture move out from the structures as quickly as required. Then, the RH between the rigid wind barrier and insulation layer (see points P6 and $\mathrm{P} 7$ in Fig. 3) will exceed the critical level and rapid mould growth is very much expected.

The mould growth risk is high if the installation starts in the cold season (with high relative humidity) or if vapour barrier layer has too high vapour resistance (e.g. PE-foil, $S_{\mathrm{d}} \geq 50 \mathrm{~m}$ ). However, it might be possible not to install a vapour barrier if the on-site installation works are started in the summer dry season, otherwise the mould growth risk is too high, especially at points P4 and P7 (wood surface, see Fig. 3). It must be analysed always in advance.

\section{Discussion}

Cost-effectiveness and advanced energy-efficient retrofit strategies, that create added value for existing building stock, have been investigated in several projects (e.g. BERTIM, E2Rebuild, Retrokit etc.) which have proved the viability of the new retrofitting solutions [30-32]. It was studied before as well that in addition to energy performance, it is necessary to pay attention to the moisture safety measures in the design of additional insulation and construction of highly insulated buildings [33]. The authors did not find comprehensive sources of analysis of hygrothermal performance of existing envelope before additional insulation and its design.

The research task, after literature review and results obtained from the analyses of the state of the original structures, was set to find combinations which are most consistent for major energy renovation, considering possible hygrothermal risks. In preceding studies [34,35] it was confirmed that the proper solution for the deep and major renovation of existing external envelopes are solutions with mineral wool with a low water vapour resistance (both for main insulation and as a wind barrier layer) and with vapour barriers/membranes with varying water vapour resistance. It was confirmed by our research that the high thermal resistance and vapour permeability of the external layers are the key components of a wellfunctioning building envelope. Solutions where water vapour resistance of the wind barrier, thermal conductivity and sensitivity to mould growth are higher compared to mineral wool (e.g. gypsum board with paper 
surface, OSB or plywood), may cause the humidity overlimit accumulation, high mould growth risk and envelope degradation.

In the context of the current study, some suggestions were made by production and construction companies for the improvement of existing prefabricated element solutions. The main way to reduce the cost (i.e. to increase efficiency and reduce time of design, production and installation) is to increase the automatization level and to find ways to unify the elements and installation. Results showed that steps taken to reduce costs decreased the hygrothermal performance. However, some moisture safe solutions $(M<1)$ and solutions with minor risk $(1 \leq M<2)$ were found. The reduction of costs by selecting materials with higher mould sensitivity is possible but hygrothermal analysis and initial moisture content measurement of the AAC panel is needed each time.

The designed thermal transmittance of the AAC wall with prefabricated timber frame insulation element is $U_{\text {external wall }}=0.14 \mathrm{~W} /\left(\mathrm{m}^{2} \cdot \mathrm{K}\right)$. This is better than needed to fulfil deep energy renovation requirements and to get the governmental grant support for deep renovation [36]. Nevertheless, Hamburg et al. [37] showed that the actual energy use for space heating of renovated buildings is frequently higher. The real heat loss of building envelopes is higher than designed because not all the thermal bridges may be not considered properly, e.g. timber columns step in walls is closer than c/c $600 \mathrm{~mm}$ etc.

In cold climate the use of a vapour tight air barrier does not cause hygrothermal risks in continuously heated residential buildings [38]. By using prefabricated insulation elements for deep energy renovation of buildings with AAC panel external walls, the vapour tight air barrier prevents drying out of the initial moisture from the original wall and causes an increase of the moisture content in the structures above the critical level. Thus, the air and vapour barrier/control layer with varying water vapour resistance is suggested. The similar performance has also been studied and shown for concrete walls [39].

\section{Conclusions}

Prefabricated timber frame elements for the additional insulation of the AAC panel walls were analysed to find the appropriate sets for the major energy renovation of apartment buildings.

The potential of drying out of the initial moisture from existing walls plays an important role in the hygrothermal performance of the building envelope. The critical initial moisture content (design value) for the surface section of the AAC panel is $65 \mathrm{~kg} / \mathrm{m}^{3}$ at a depth of $15 \mathrm{~mm}$ and $39 \mathrm{~kg} / \mathrm{m}^{3}$ at a depth of $70 \mathrm{~mm}$.

The best choice of material for a wind barrier based on hygrothermal performance is mineral wool with an airtight external surface. If a rigid wind barrier is required because of prefabrication effectiveness and to guarantee the angularity of the element, the vapour permeable fibre cement board could be chosen, considering at the same time the actual moisture loads.
The propagating way to introduce and disseminate the subject of prefabricated timber frame insulation elements as a way of using renewable wood resources and their benefits to the decision makers is to put researchers, producers and installers' efforts on R\&D, automatization and innovation to attract more attention on the market and to invite users to consider sustainable and smart solutions applicable to nZEB.

It is essential to continue to study the timber frame insulation elements and their hygrothermal performance on other types of structures as well. There are lot of apartment and office buildings with poor thermal efficiency and unsatisfying indoor climate, constructed decades ago. The use of timber frame insulation elements for their improvement might be a good option.

The authors gratefully acknowledge the financial support by H2020 projects no. 841850 'DRIVE 0 - Driving decarbonisation of the EU building stock by enhancing a consumer centred and locally based circular renovation process' and no. 856602 'Finest Twins'; the Estonian Research Council with personal research funding grant PRG483 'Moisture safety of interior insulation, constructional moisture, and thermally efficient building envelope'; Estonian Centre of Excellence in Zero Energy and Resource Efficient Smart Buildings and Districts (grant no. TK146) funded by the European Regional Development Fund.

\section{References}

1. R. Miniotaite, in ISEC 2015 - 8th International Structural Engineering and Construction Conference: Implementing Innovative Ideas in Structural Engineering and Project Management (Sydney, Australia, 2015), pp. 1247-1252

2. P. Femenías, K. Mjörnell, and L. Thuvander, Journal of Cleaner Production 195, 1457 (2018)

3. K. Kuusk and T. Kalamees, Building Research \& Information 44, 920 (2016)

4. S. Ilomets, K. Kuusk, L. Paap, E. Arumägi, and T. Kalamees, Journal of Civil Engineering and Management 23, 96 (2017)

5. A. Mikola, T. Kalamees, and T.-A. Kõiv, in 11th Nordic Symposium on Building Physics, NSB2017, 11-14 June 2017, Trondheim, Norway, in Energy Procedia (Elsevier, 2017), pp. 963-968

6. J. Hirvonen, J. Jokisalo, J. Heljo, and R. Kosonen, Energies 12, 4395 (2019)

7. T. Kalamees, A. Lupišek, O. C. Mørck, A. Borodinecs, M. Almeida, R. Rovers, P. O. Veld, K. Kuusk, and S. Silva, in Central Europe Towards Sustainable Building 2016: Innovations for Sustainable Future, CESB 2016 (CESB 2016, Prague, Czech Republic, 2016), pp. 137-144

8. K. Kuusk, T. Kalamees, S. Link, S. Ilomets, and A. Mikola, Journal of Civil Engineering and Management 23, 67 (2016)

9. A. Kaklauskas, E. K. Zavadskas, and S. Raslanas, Energy and Buildings 37, 361 (2005)

10. R. Gupta and M. Gregg, Energy and Buildings 


\section{9, $330(2016)$}

11. S. Varela Luján, C. Viñas Arrebola, A. Rodríguez Sánchez, P. Aguilera Benito, and M. González Cortina, Sustainable Cities and Society 51, (2019)

12. S. Ximenes, J. Brito, P. Gaspar, and A. Silva, Materials and Structures 48, (2015)

13. V. Sulakatko, E. Liisma, and E. Soekov, Procedia Environmental Sciences 38, 765 (2017)

14. H. Künzel, H. M. Künzel, and K. Sedlbauer, ACTA Architectura 5, 11 (2006)

15. K. Sandberg, T. Orskaug, and A. Andersson, in SBE16 Tallinn and Helsinki Conference Build Green and Renovate Deep, SBE2016, 5-7 October 2016, Tallinn and Helsinki (Energy Procedia, 2016), pp. 756-767

16. K. Mjörnell, in Case Studies of Building Pathology in Cultural Heritage, edited by J. M. P. Q. Delgado (Springer Singapore, 2016), pp. 95113

17. P. O. Veld, in 6th International Building Physics Conference IBPC2015 (Energy Procedia, 2015), pp. 1057-1062

18. P. Pihelo, T. Kalamees, and K. Kuusk, in 11th Nordic Symposium on Building Physics, NSB2017, 11-14 June 2017, Trondheim, Norway, edited by $\mathrm{S}$. Geving and B. Time (Energy Procedia, 2017), pp. 1006-1011

19. A. Tisov, K. Kuusk, P. Pihelo, M. N. Escudero, M. N. Assimakopoulos, P. O. Veld, and T. Kalamees, in NSB2020 12th Nordic Symposium on Building Physics, 14-17.06.2020 (EDP Sciences. E3S Web of Conferences [submitted], Tallinn, Estonia, 2020)

20. K. Kuusk, Integrated Cost-Optimal Renovation of Apartment Buildings toward Nearly Zero-Energy Buildings, Tallinn University of Technology, 2015

21. J. Grunewald, Diffusiver Und Konvektiver StoffUnd Energietransport in Kapillarporösen Baustoffen (Dresden Univeristy of Technology, 1997)

22. A. Nicolai, Modeling and Numerical Simulation of Salt Transport and Phase Transitions in Unsaturated Porous Building Materials (Syracuse University, 2008)

23. P. Pihelo and T. Kalamees, Wood Material Science \& Engineering 03/07, (2019)

24. T. Kalamees and J. Vinha, Journal of Building Physics 27, 199 (2004)

25. S. Ilomets, T. Kalamees, and J. Vinha, Journal of Building Physics 41, 547 (2017)

26. A. Hukka and H. Viitanen, Wood Science and Technology 33, 475 (1999)

27. T. Ojanen, H. Viitanen, R. Peuhkuri, K. Lähdesmäki, J. Vinha, and K. Salminen, in Thermal Performance of the Exterior Envelopes of Buildings XI (ASHRAE, Clearwater Beach,
USA, 2010)

28. H. Viitanen, M. Krus, T. Ojanen, V. Eitner, and D. Zirkelbach, 6th International Building Physics Conference IBPC2015 78, 1425 (2015)

29. EN 1353, Determination of Moisture Content of Autoclaved Aerated Concrete (Brussels, 1996)

30. T. Heim, D. Ehrbar, and P. Schwehr, Technical Report: Industrial Energy Efficient Retrofitting of Resident Buildings in Cold Climates (E2Rebuild, 2014)

31. A. Katsifaraki, B. Bueno, T. Kuhn, and C. Maurer, Technical Report: Assessment of a Photovoltaic Thermal (PVT) Prefabricated Facade (Retrokit, 2014)

32. N. Tellado, T. Linner, J. Guettler, K. Iturralde, T. Bock, M. Fredriksson, Y. Sebesi, J. Sjostrom, M. Brännström, H. Coperet, Z. Mandrara, J.-L. Kouyoumji, N. Lasarte, W. Pan, K. Langosch, T. Kinoshita, D. Krysiński, and R. Mielczarek, in 9th Forum International Bois Construction FBC2019 (2019)

33. F. Lattke, K. Larsen, S. Ott, and Y. Cronhjort, Technical Report: TES Energy Facade Prefabricated Timber Based Building System for Improving the Energy Efficiency of the Building Envelope (Woodwisdom Net, 2009)

34. P. Pihelo and T. Kalamees, Journal of Building Engineering 6, 29 (2016)

35. T. Colinart, M. Bendouma, and P. Glouannec, Energy and Buildings 186, 221 (2019)

36. K. Kuusk and T. Kalamees, Energy Procedia 96, 628 (2016)

37. A. Hamburg and T. Kalamees, Energy and Buildings 199, 332 (2019)

38. J. Vinha, Hygrothermal Performance of TimberFramed External Walls in Finnish Cimatic Conditions: A Method of Determing a Sufficient Water Vapour Resistance of the Internal Lining of a Wall Assembly (Tampere University of Technology, Publication 658, 2007)

39. P. Pihelo, M. Lelumees, and T. Kalamees, in SBE16 Tallinn and Helsinki Conference Build Green and Renovate Deep, SBE2016, 5-7 October 2016, Tallinn and Helsinki, edited by J. Kurnitski (Energy Procedia, 2016), pp. 745-755 